\title{
Evaluating the Transborder Urban-Cluster Alternatives Suitable for Regional Development Concept of Mongolia
}

\author{
Tseyenkhand Punsantsogvoo ${ }^{1, *}$, Altanbagana Myagmarsuren ${ }^{1}$ \\ ${ }^{1}$ Institute of Geography and Geoecology, Mongolian Academy of Sciences, Ulaanbaatar, Mongolia \\ "Corresponding author. Email: tseyenkhandp@mas.ac.mn
}

\begin{abstract}
Mongolia is a country with a large territory, has abundant natural resources, and is located between the two great powers, Russia and China. For this reason, a transborder urban cluster can be a significant tool to support agriculture, tourism, trade, and further education, health, and transport sectors. Within the framework of this research, we aim to identify key concepts of a transborder urban cluster, which are suitable for Mongolian conditions, and make qualitative, quantitative, and spatial analysis on this cluster by the means of certain criteria and Analytic Hierarchy Process (AHP). We selected eight transborder urban cluster alternatives connecting four with Russia and four with China. Compared to other alternatives, the Ulan-Ude-Sukhbaatar urban cluster has the lowest distances between the two cities, free economic zones, transit of international border crossings, and good transport conditions; therefore, the cluster received the highest score in this study. In the current study, the proposed alternatives were evaluated using the AHP method.
\end{abstract}

Keywords: Transborder Urban cluster, AHP method, Regional development, Economic corridor

\section{INTRODUCTION}

Clusters are geographic concentrations of interconnected companies and institutions in a particular field. Clusters encompass an array of linked industries and other entities, important to competition. They include, for example, suppliers of specialized inputs such as components, machinery, services, and providers of specialized infrastructure [1].

In recent years, different studies on urban clusters have been conducted. There are many advantages of clustered urbanization such as integrated urban infrastructure and services; increased private sector interest and investment; collaborative and participatory governance; balanced and inclusive development of the region and better environmental protection [2].

City clusters in Asia fall into at least four types in terms of geo-spatial forms: urban corridors, megacity-dominated clusters, subnational regional clusters, and transborder clusters [3]. These types of clusters are distinguished by their population, the geographic area they cover, planning and governance mechanisms and their spheres of economic and social influence in the context of the particular regions where they are located [3]. Almaty in Kazakhstan and Bishkek in Kyrgyzstan are large examples of transborder urban cluster [4].

Transborder urban cluster is concerned with the spatial organization of economic activities. It brings together existing and new infrastructure, policies, and institutions to attract private investment that will create jobs and encourage economic growth [5].

The concept of urban clusters is a relatively new topic in Mongolia. Regional development is very important for Mongolia and urban cluster can be significant tools to support it [6].

According to the survey, Mongolia's population was relatively stable from 1990 to 2001. However, since 2001, migration to the central areas has increased dramatically and the population of 254 soums has decreased [7]. From 1995 to 2014, a total of 480000 people moved from rural areas to Ulaanbaatar [8]. As of 2020, 47.6 percent of the 
country's population lives in Ulaanbaatar, and if this trend continues, $62 \%$ is expected to settle by 2040 [9]. As a result, there is social and economic overcentralization at only one point. Therefore, it could negatively impact the potential conditions for population, construction and infrastructure use in the eastern, western and remote regions.

China and Russia-two geographical neighbors of Mongolia are the most influential countries in terms of social, economic, trade, industrial and foreign relations. The development of a transborder urban cluster connected to neighboring countries through the rational use of economic corridors will provide new opportunities to maintain sustainable population growth, increase employment, and expand the development of road transport, foreign trade, exports, and imports.

The transborder urban cluster is a concept that connects cities along the Mongolian border with cities of neighboring country in terms of infrastructure, trade, and services to create a cluster city and develop in an interconnected manner. Within the framework of this research, we aim to identify key concepts of a transborder urban cluster, which are suitable for Mongolian conditions, and make qualitative, quantitative, and spatial analysis on this cluster by the means of certain criteria and AHP.

\section{METHODS}

\subsection{Key concepts and criteria}

Different literary sources, Mongolian legislation, development policy and documents, official statistical data, foreign and domestic reports of regional development and population settlement, were used during the determining key concepts of transborder urban cluster for suitable Mongolia. Afterwards, six indicators (population, urbanization, development potential, power capacity, border crossing type and distance) were used to show whether the transborder urban cluster could satisfy the criteria and concepts.

Article 3.1 of the Law on the Legal Status of Towns and Villages of Mongolia states that "a city is a self-governing settlement with at least 15000 inhabitants, most of who work mainly in industry and services, with well-developed urban infrastructure" is indicated. So we selected cities with more than 15000 inhabitants in transborder urban cluster. For urbanization, the population change was calculated by comparing the population growth of 1990-2000, 2000-2010, and 2010-2019 [7] with the average population growth of the country. The development potential of the industrial sector was clarified by using a result of the atlas named "Development of integrated industrial location planning and mapping methodology" [10]. For a transborder urban cluster, the most important criteria are the distance between the two cities and the capacity of border crossing. We used the existing border crossing classification as a criterion. Also the horizontal and vertical main axes of Mongolia are proposed based on 19 indicators from 9 groups [11], and a transborder urban cluster should be planned based on this axis. Cities connected to the energy source are classified according to their energy capacity.

\subsection{Analytic Hierarchy Process}

The above criteria and alternatives were evaluated using AHP approach to select the most appropriate cluster city for the Mongolian context. The method of pairwise comparison of criteria suggested by Saaty (1980) and widely known as the AHP is well suited. This approach allows the researchers to determine the weights of the criteria of the same hierarchical level with respect to higher level criteria or to determine hierarchically unstructured criteria weights. The most appropriate alternative was evaluated in the following steps.

1. Structuring the problem and building the AHP model

2. Collecting the data

3. Pairwise comparison of each factor

4. Calculation of consistency index to rank optimization requirement of each risk.

Measure of consistency (i.e. consistency index) is determined as a deviation or degree of consistency using the following formula [12].

$\mathrm{CI}=\frac{\lambda \max -\mathrm{n}}{\mathrm{n}-1}$

Where:

$\lambda$ max-maximum eigenvalue

$\mathrm{N}$-number of matrix.

Then, consistency ratio, which is a comparison between consistency index and random consistency index, can be derived as shown below:

$\mathrm{CR}=\mathrm{CI} / \mathrm{RI}$

CI-consistency index

RI-random consistency index.

\section{RESULTS AND DISCUSSION}

The key concepts of the transborder urban cluster were developed using different literary sources, 
Mongolian legislation, development policy and documents, official statistical data, foreign and domestic reports. The main concepts and requirements of the transborder cluster suitable for Mongolian conditions have been identified as shown in Table 1.

Table 1. Key concepts and requirements of transborder urban cluster

to be developed for Regional Development Issues in the Mongolia

\begin{tabular}{|c|c|c|}
\hline \multicolumn{2}{|c|}{ Type of cluster } & Transborder urban cluster \\
\hline \multicolumn{2}{|c|}{ Description of cluster } & $\begin{array}{l}\text { A transborder urban cluster is a concept that connects cities along the Mongolian } \\
\text { border with cities of neighboring country in terms of infrastructure, trade, and } \\
\text { services to create a cluster city and develop in an interconnected manner. }\end{array}$ \\
\hline \multirow{5}{*}{ 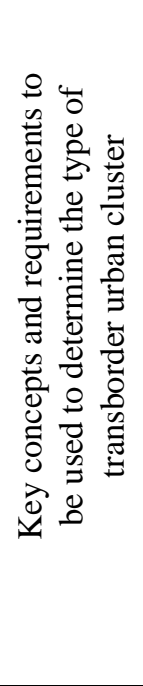 } & Population & $\begin{array}{l}\text { It shall be cities having state and provincal ranking, population of more than } \\
15000 \text {, is located near the state border. }\end{array}$ \\
\hline & Economy & $\begin{array}{l}\text { Border cities with transit transportation, logistics and development gateways for } \\
\text { foreign trade, exports and imports will be developed by creating a cluster with } \\
\text { neighboring cities and ensuring sustainable economic growth. }\end{array}$ \\
\hline & $\begin{array}{c}\text { Infrastructure, } \\
\text { transportation } \\
\text { and logistics }\end{array}$ & $\begin{array}{l}\text { 1) Located at node or along of national vertical and horizontal axes (including } \\
\text { international and national roads, railways and economic corridors) and connected } \\
\text { to each other by road and rail; 2) Regional level transportation and logistics center; } \\
\text { 3) Includes cities connected to energy sources with outskirt and neighbouring } \\
\text { soums and villages. }\end{array}$ \\
\hline & $\begin{array}{l}\text { Geographical } \\
\text { and spatial } \\
\text { location }\end{array}$ & $\begin{array}{l}\text { In terms of geographical location: 1) Close to the state border; 2) Close to } \\
\text { international immigration ports and Free Economic Zones. }\end{array}$ \\
\hline & $\begin{array}{c}\text { Coherence of } \\
\text { development } \\
\text { policy and } \\
\text { planning }\end{array}$ & $\begin{array}{l}\text { Border cities will need to develop coordinated development policies and plans } \\
\text { with each other in terms of trade, exports, imports, transportation, and logistics. }\end{array}$ \\
\hline
\end{tabular}

Source: Altanbagana M. 2019. Basic research project on "Re-Development the Integrated Basis Method for Regional Development Concept of Mongolia"

For the analysis, we selected 8 Mongolian cities that could meet the above criteria and created a cluster with the nearest neighboring city. When these eight cities are connected to the nearest major cities along the economic corridor, four will create a transborder cluster with Russian cities and the leftover four with Chinese cities (Figure 1). The eight alternatives were assessed using the AHP method within the framework of the six main criteria.

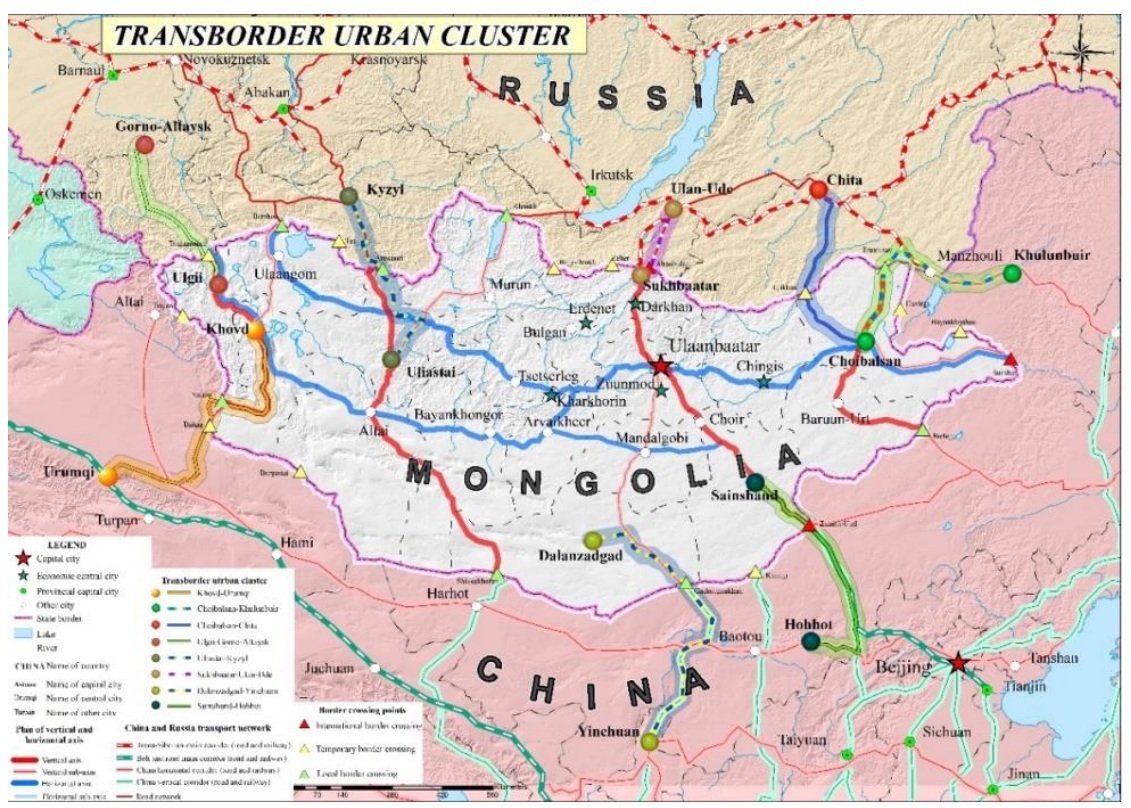

Figure 1. Transborder Urban Cluster Alternatives for Regional Development Policy Making 
The Ulan-Ude-Sukhbaatar cluster received the highest score in the analytical hierarchy of eight alternatives for transborder clusters (Table 2). Compared to other alternatives, the cluster has the lowest distances between the two cities, free economic zones, transit of international border crossings, and good transport conditions.

Table 2. Final evaluation using an Analytical Hierarchical Process (AHP)

\begin{tabular}{|l|r|r|r|r|r|r|r|}
\hline \multicolumn{1}{|c|}{ Criteria } & Population & $\begin{array}{c}\text { Urbanizatio } \\
\mathbf{n}\end{array}$ & $\begin{array}{c}\text { Development } \\
\text { potential }\end{array}$ & $\begin{array}{c}\text { Energy } \\
\text { capacity }\end{array}$ & $\begin{array}{c}\text { Border } \\
\text { crossing type }\end{array}$ & Distance & GOAL \\
\hline Choibalsan-Khulunbuir & 0.012 & 0.015 & 0.004 & 0.001 & 0.027 & 0.023 & $\mathbf{0 . 0 6 1}$ \\
\hline Dalanzadgad-Yinchuan & 0.003 & 0.012 & 0.004 & 0.018 & 0.013 & 0.008 & $\mathbf{0 . 0 5 7}$ \\
\hline Sainshand-Hohhot & 0.001 & 0.015 & 0.026 & 0.021 & 0.050 & 0.032 & $\mathbf{0 . 1 4 4}$ \\
\hline Khovd-Urumqi & 0.001 & 0.035 & 0.026 & 0.021 & 0.030 & 0.032 & $\mathbf{0 . 1 6 4}$ \\
\hline Ulgii-Gorno-Altaysk & 0.001 & 0.015 & 0.026 & 0.003 & 0.030 & 0.032 & $\mathbf{0 . 1 2 6}$ \\
\hline Uliastai-Kyzyl & 0.006 & 0.035 & 0.009 & 0.027 & 0.007 & 0.032 & $\mathbf{0 . 1 1 7}$ \\
\hline Choibalsan-Chita & 0.003 & 0.035 & 0.026 & 0.038 & 0.018 & 0.032 & $\mathbf{0 . 1 5 1}$ \\
\hline Sukhbaatar-Ulan-Ude & 0.033 & 0.035 & 0.026 & 0.028 & 0.048 & 0.032 & $\mathbf{0 . 1 8 1}$ \\
\hline
\end{tabular}

The proposed alternatives were evaluated using the AHP method. However, in order to improve the quality of the research, the results should be confirmed by further policy research. Although the distance between the two cities and the conditions of the economic corridors are important, the transborder urban cluster should have the highest level of impact on the country's economy, foreign trade and industry.

Mongolian territory stretches from Central Asia to Northeast Asia, therefore, it is an important aspect to join the regional economic integration, and initiating major infrastructure projects with neighboring countries, and developing the economic corridor cooperation in harmonization with Mongolia's foreign policy [13]. In the Concept of Mongolia's Foreign Policy 21 proposed policy target, 21.4. Striving to join international and regional economic integration and infrastructure networks, reaching the seaport and supporting the creation of favorable conditions for transit roads and transportation which were approved by the Parliament [14]. This transborder urban cluster will support regional trade turnover.

Table 3. Educational and health institutions, by province

\begin{tabular}{|l|l|c|c|c|}
\hline Province name & Province center & $\begin{array}{c}\text { Universities, institutes and } \\
\text { colleges }\end{array}$ & $\begin{array}{c}\text { Regional diagnostic } \\
\text { and treatment } \\
\text { center }\end{array}$ & $\begin{array}{c}\text { Central and } \\
\text { specialised } \\
\text { hospital }\end{array}$ \\
\hline Khovd & Khovd & 1 & 1 & 1 \\
\hline Bayan-Ulgii & Ulgii & - & - & - \\
\hline Zavkhan & Uliastai & - & - & 1 \\
\hline Selenge & Sukhbaatar & - & - & 1 \\
\hline Dornogobi & Sainshand & - & 1 & - \\
\hline Dornod & Choibalsan & 1 & 1 & - \\
\hline Umnugobi & Dalanzadgad & - & - & 1 \\
\hline
\end{tabular}

The trans-border urban cluster creates opportunities for economic, foreign trade, and tourism development with the neighbors. Mongolia has two neighbors, Russia and China, and the majority of international passengers crossing the border are citizens of the two neighbors. For instance, in 2020, 35.9 million foreign passengers crossed the Mongolian-Chinese border, while 62 million foreign passengers crossed the Mongolian-Russian border. In addition, 23 percent of foreign tourists visiting Mongolia in 2020 came from China and about 50 percent from Russia [15]. As of 2019, the total trade turnover had reached 13747.1 million US dollars, and $64 \%$ of the total foreign trade turnover was with China and $13 \%$ with Russia. In addition, $89 \%$ of total exported products were exported to China, $33.5 \%$ and $28.2 \%$ of total imported products were imported from China and Russia respectively.

Moreover, some cities along the borders have universities and health centers, so it is possible to develop trade, industry, education, science, and technology centers by establishing trans-border urban clusters (Table 3). 


\section{CONCLUSIONS}

The starting point for the transborder urban cluster is selecting and prioritizing the target geographical areas based on identified socioeconomic potential. Furthermore, the results obtained using policy analysis should be evaluated in more detail.

Transborder cluster gives both countries the chance to design cooperation and coordinate the steps toward each other. In line with modern development trends in the form of urban clusters, it is possible to decentralize the population, create large cities at the regional level, create a stable and balanced population, and support the development of remote border areas.

Mongolia's foreign relations program includes regional economic cooperation, but it is still unclear in which regions and cities the integration strategy should be developed. Therefore, there is an urgent need for scientific identification and thorough research study.

\section{REFERENCES}

[1] Porter M. (1998). On competition. Boston: Harvard business school press.

[2] Shikha, Sangeetha, \& Siddhant. (2019). Exploring strategies for planned urban cluster development in South Asia. Asian develpment bank.

[3] Choe, K., \& Laquian, A. (2008). City cluster development: toward an urban-led development strategy for Asia. Asian development bank.

[4] ADB. (2017). CAREC 2030 connecting the region for shared and sustainable development. Manila: Asian development bank.

[5] Srivastava, P., (2016). Growing together: Almaty-Bishkek Corridor Initiative Investment Framework. Manila: Asian development bank.

[6] Altanbagana M. (2019). Re-Development the Integrated Basis Method for Regional Development Concept of Mongolia.
Ulaanbaatar: Institute of Geography and Geoecology, MAS.

[7] Altanbagana M. (2016). Consulting on "National Report of Urban Development of Mongolia for UN HABITAT III" and "Current Assessment for Regional and Human Settlements Development in Mongolia". Equador: Ministry of Construction and Urban Development and UNDP.

[8] Altanbagana M. (2018). Sustainable Development Vision 2030 and Challenges in Mongolia: Zud Impact on Social-Economic Issues. Changing Environment and People's lives of Mongolia. Japan: Tottori University.

[9] Enkhbaigali, B., Tumurpurev, D., \& Altanbagana, M. (2016). Sustainable Development Concept of Mongolia 2040. Ulaanbaatar: The National Development Institute of Mongolia.

[10] Battogtokh, D., Altanbagana, M., \& Sainbuyan, B. (2018). Development of integrated industrial location planning and mapping methodology. Ulaanbaatar: Institute for Geography and Geoecology, MAS.

[11] Altanbagan, M., \& Urantamir, G. (2020). The transport network and logistics perspective . Ulaanbaatar: Construction Development Center.

[12] Technomo, K., (2010). Analytic hierarchy process (AHP) tutorial.

[13] Altanbagana M. (2020). Spatial Analysis on Social, Economic and Urbanization of CAREC 4a Corridor. Institute of Geography and Geoecology, MAS.

[14] State Great Khural. (2015). Mongolia's Economic Foreign Relations Program. The resolution of Government of Mongolia of 2015 №474.

[15] NSO. (2020). National Statistical Office of Mongolia. Retrieved from www.1212.mn 